
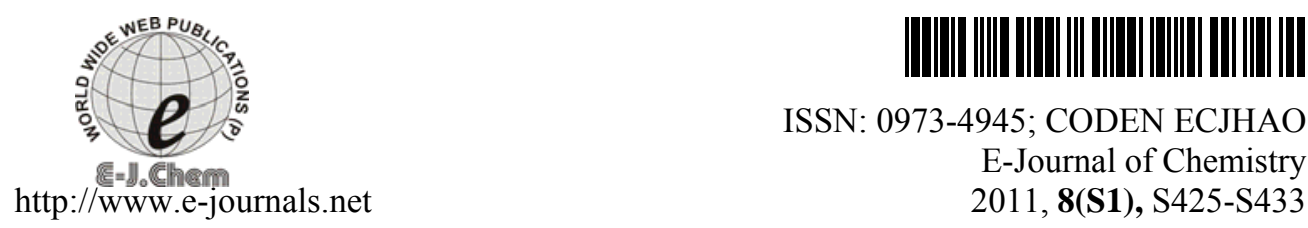

ISSN: 0973-4945; CODEN ECJHAO

E-Journal of Chemistry

2011, 8(S1), S425-S433

\title{
Determination of Trace Amount of Pd(II) and Ni(II) with Newly Synthesized Pyrozlon Azo Bromo Phenol by Spectrophotometric Methods
}

\author{
HUSSAIN J MOHAMMED*, AZHAR Y MUHI ${ }^{\S}$ and \\ HAYDER AL MEISSLEMAW
}

\author{
*Faculty of Dentistry, Dept. of Basic Science, Kufa University, Iraq \\ ${ }^{\S}$ Faculty of Education for Women, Dept. of Chemistry, Kufa University, Iraq \\ Faculty of Education Ibn Al-Haithem, Dept. of Chemistry, Baghdad University, Iraq \\ ibrahiem_af@yahoo.com
}

Received 1 March 2011; Accepted 27 April 2011

\begin{abstract}
A sensitive and selective method has been developed for the determination of palladium(II) and nickel(II). A new reagent and two complexes have been prepared in aqueous solutions. The method is based on the chelation of metal ions with 4-(ל- antipyriyl azo ) -2-bromo phenol (APBP) to form an intense color soluble products, that are stable and have a maximum absorption at $498 \mathrm{~nm}$ and at $433.5 \mathrm{~nm}$ and $\varepsilon_{\max }$ of $0.21 \times 10^{4}$ and. $0.38 \times 10^{4}$ Lmole $\mathrm{cm}^{-1}$ for Pd(II) Ni(II) respectively. A linear correlation of $(0.2-3)$ and $(0.6-2.2) \mathrm{ppm}$ for $\mathrm{Pd}(\mathrm{II}) \mathrm{Ni}(\mathrm{II})$ respectively. The stoichiometry of both complexes was found to be 1:2 (metal:ligand). The effect of various cations and anions on $\mathrm{Pd}(\mathrm{II})$ and $\mathrm{Ni}(\mathrm{II})$ determination have been investigated. The stability constants $\mathrm{Pd}(\mathrm{II})$ and $\mathrm{Ni}(\mathrm{II})$ were $0.37 \times 10^{8}, 0.38 \times 10^{8} \mathrm{~L} \mathrm{~mol}^{-1}$ respectively. The conductivity measurements for complexes are consistent with those expected for an electrolyte. The optimum conditions for full color development for described methods were applied satisfactorily to synthetic mixtures samples and biological samples.
\end{abstract}

\section{Introduction}

Palladium finds very important and extensive use in alloys, catalysts and in low voltage electrical contacts. Hence, its recovery, purification and determination palladium have been reported $^{1-5}$. Azo -dyes widely used in analytical chemistry because of their ability to form coloured complex with many metal ion in water. In recent years they have been employed in sorption spectroscopic test method more extensively then in conventional spectrophotometry ${ }^{6}$. The literature survey reveals different analytical methods for the determination of $\operatorname{Pd}(\mathrm{II})$ in 
Jewelry and biological samples; these methods $^{7}$ (ETAAS), flam atomic absorption (FAAS) ${ }^{8}$, optical test strip for spectrophotometry ${ }^{9}$ and stripping voltammetry ${ }^{10}$. Azo compounds are know to be involved in a number of biological reaction such as inhibition of DNA, RNA and protein synthesis ,carcinogenesis and nitrogen fixation ${ }^{11}$. Azo pyrazole derivatives and its metal complexes can be used as inkjet, they have got fastness properties for dying papers ${ }^{12}$ and process high dying power on fibers ${ }^{13}$. They can also be used in subtractive photographic process and for the production of color transparences and color pictures ${ }^{14}$ and have many applications ${ }^{15}$. Various methods for the assay of nickel(II) have been reported. adsorptive stripping voltammetry ${ }^{16,17}$, reverse phase high performance liquid chromatography ${ }^{18,19}$, flame and electro thermal atomic absorption ${ }^{20-22}$, flow injection and flow injectioninductively coupled plasma optical emission spectrometry ${ }^{23,24}$ and simple spectro photometric methods ${ }^{25-28}$. The aim of the present work is to develop an easy, rapid method for the determination of palladium(II). The method is based on the reaction of 4(4-antipyriyl azo)-2-bromophenol (APBP), with forms coloured complexes which forms coloured complexes with $\mathrm{Pd}(\mathrm{II})$ and $\mathrm{Ni}(\mathrm{II})$ ions.

\section{Experimental}

All chemical used were of analytical grade.

\section{Apparatus}

Spectrophotometric measurements were made with shimadzu UV-Visible -1700 double beam spectrometric using (1.0) cm glass calls. The $\mathrm{pH}$ measurements were performed with AWTW pH -meter 720. Electric molar conductivity measurements were carried out at room temperature using an Alpha digital conductivity model -800. Vibration spectra were recorded by Testscan Shimadzu FT.IR 8000 series.

\section{Preparation of reagent (APBP)}

The reagent was prepared by coupling resorcinol with diazotate 4-amino antipyrin in alkaline alcoholic solution. A diazonium solution was prepared by taking $1 \mathrm{~g}$ 4-amino antipyrin in $15 \mathrm{~mL}$ of ethanol and concentrated hydrochloric acid with $5 \mathrm{~mL}$ of distilled water and adding sodium nitrite solution drop wise at $0-5{ }^{\circ} \mathrm{C}$. 2- Bromophenol $1.2 \mathrm{~g}$ was dissolved in $50 \mathrm{~mL}$ of ethanol and $30 \mathrm{~mL}$ of $0.1 \mathrm{M}$ were added at $\left(-5^{\circ} \mathrm{C}\right)$. The mixture was left to stand over night. The precipitate was filtered off and recrystallized from ethanol ${ }^{29}$ Scheme 1.

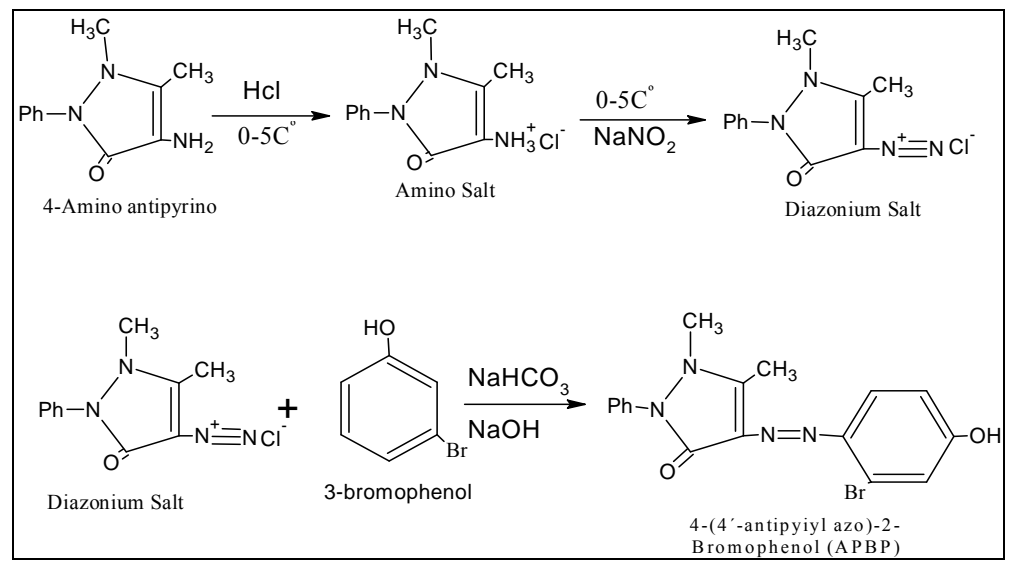

Scheme 1. Preparation of reagent APBP 


\section{Preparation of palladium(II) complex}

The complex was prepared by stoichiometric amount from ligand in $50 \mathrm{~mL}$ of ethanol then added drop wise with stirring to a stoichiometric amount 1:2 for palladium salt in $(25) \mathrm{mL}$ hot distilled water. The solid product thus formed off, washed with ethanol and dried.

\section{Preparation of nickel(II) complex}

The complex was prepared by stoichiometric amount from ligand in $50 \mathrm{~mL}$ of ethanol then added drop wise with stirring to a stoichiometric amount 1:2 for nickel salt in $25 \mathrm{~mL}$ hot distilled water. The solid product thus formed off, washed with ethanol and dried.

\section{Reagents}

\section{Palladium(II) stock solution (1000 $\left.\mu \mathrm{g} . \mathrm{mL}^{-1}\right)$}

$0.3330 \mathrm{~g}$ of $\mathrm{PdCl}_{2}$ was dissolved in $10 \mathrm{~mL}$ of $1 \mathrm{M} \mathrm{HCl}$ and diluted to $100 \mathrm{~mL}$ using distilled water, working standard $\mathrm{Pd}(\mathrm{II})$ solution were prepared by dilution of the appropriate volume of standard Pd(II) solution ( $100 \mu \mathrm{g} / \mathrm{mL})$ with distilled water.

Nickel(II) stock solution (200 $\left.\mu \mathrm{g} \mathrm{mL}^{-1}\right)$

$0.4033 \mathrm{~g}$ of $\mathrm{NiCl}_{2} \cdot 6 \mathrm{H}_{2} \mathrm{O}$ was dissolved in $500 \mathrm{~mL}$ of distilled water, working standard $\mathrm{Ni}$ (II) solution were prepared by dilution of the appropriate volume of standard $\mathrm{Ni}$ (II) solution $(100 \mu \mathrm{g} / \mathrm{mL})$ with distilled water.

4-(4- Antipyriyl azo ) -3-Bromo phenol $\left(1 \times 10^{-4} \mathrm{M}\right)$

$0.0086 \mathrm{~g}$ of Regent (APBP) was dissolved in $250 \mathrm{~mL}$ of ethanol working (APBP).

Foreign ion solutions (100 $\left.\mu \mathrm{g} \mathrm{mL}^{-1}\right)$

These solutions were prepared by dissolving an amount of the compound in distilled water completing the volume in a volumetric flask.

\section{Recommended procedure for determination of Pd (II) and Ni(II)}

In to a series of $10 \mathrm{~mL}$ calibrated flask, increasing volume of $\mathrm{Pd}(\mathrm{II})$ and $\mathrm{Ni}(\mathrm{II})$ working solutions $\left(100 \mu \mathrm{g} \mathrm{mL}^{-1}\right)$ to the range of the calibration curve was transfered, $2.0 \mathrm{~mL}$ of $5 \times 10^{-4} \mathrm{M}$ of (APBP) for both ions was added. The $\mathrm{pH}(4.0,8.0)$ for $\mathrm{Pd}(\mathrm{II})$ and $\mathrm{Ni}(\mathrm{II})$ was adjusted by $\mathrm{NH}_{3}$ and $\mathrm{CH}_{3} \mathrm{COOH}$ for $\mathrm{Pd}(\mathrm{II})$ and $0.05 \mathrm{M} \mathrm{HCl}$ and $\mathrm{NaOH}$ for $\mathrm{Ni}(\mathrm{II})$ respectively. The complexes formed were solubilized in water and diluted up to $10 \mathrm{~mL}$ with distilled water. The concentration range $0.2-3 \mu \mathrm{g} / \mathrm{mL}$ and $0.6-2.2 \mu \mathrm{g} / \mathrm{mL}$ of $\mathrm{Pd}(\mathrm{II})$ and $\mathrm{Ni}(\mathrm{II})$, respectively. Measure the absorbance at 498 $\mathrm{nm}$ for $\mathrm{Pd}(\mathrm{II})$ and at $498 \mathrm{~nm}$ for $\mathrm{Ni}(\mathrm{II})$ complexes against a reagent blank.

\section{Results and Discussion}

Properties of APBP and its metal chelates APBP is a bidentate with coordination of azo group nitrogen and carbonyl groups; it has following structure (Scheme 2)

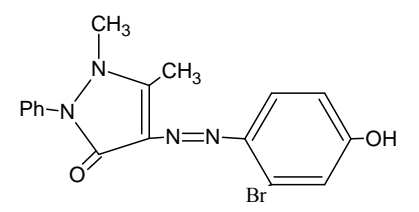

Scheme 2. Structure of 4-('̀- antipyriyl azo )-2-bromophenol (APBP)

Owing to the large conjugated, the compound showed excellent chelation ability to form metal chelates. APBP and its metal chelates can be easily dissolved in aqueous solutions. 


\section{Mechanism of reagent reaction}

The reaction sequence in procedure of reagent involves tow steps. First, 4-amino antipyrine react with nitrite to form diazoniuum ion; the second including the diazanium ion is coupling with 2-bromophenol to form dark yellow azo dye ${ }^{16}$ (Scheme 1). The effect of various parameters on the absorbance intensity of the formed products was studied and the reaction conditions were optimized.

\section{Absorption spectra}

The results of this investigation indicated that the reactions of $\mathrm{Pd}(\mathrm{II})$ and $\mathrm{Ni}$ (II) with 4(4-pyrazolon azo) -2- bromophenol yields highly soluble colored complexes which can be utilized as a suitable assay procedure for determination of $\mathrm{Pd}(\mathrm{II})$ and $\mathrm{Ni}(\mathrm{II})$. These colored complexes have a maximum a absorption at $498 \mathrm{~nm}$ for $\mathrm{Pd}(\mathrm{II})$ and at $498 \mathrm{~nm}$ for $\mathrm{Ni}(\mathrm{II})$, the blank at these wavelengths shows zero absorbance Figure $1 \& 2$.

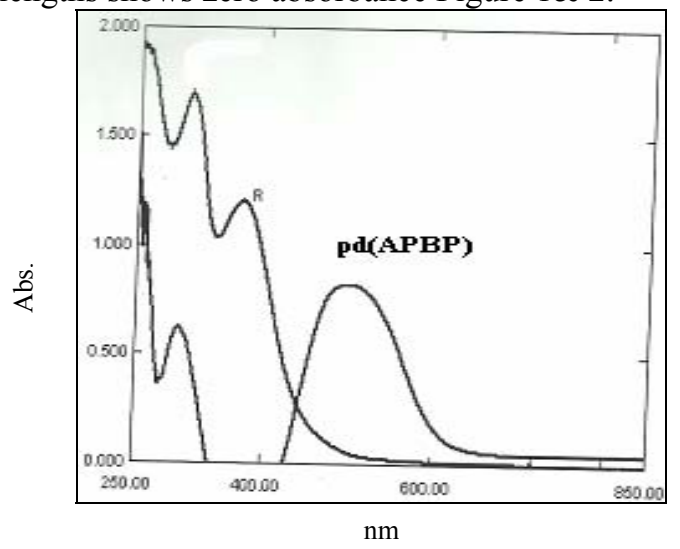

Figure 1. Absorption spectra of (R-Pd) treated as described under procedures and measured against a reagent blank and $\mathrm{R}$ the reagent blank against ethanol

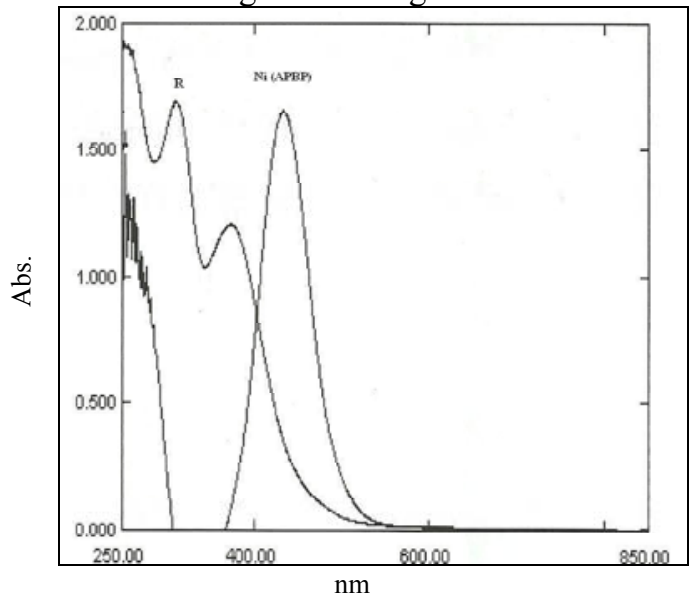

Figure 2. Absorption spectra of (R-Ni) treated as described under procedures and measured against a reagent blank and $\mathrm{R}$ the reagent blank against ethanol

The effect of various parameters on the absorption intensity of the formed products was studied and the reactions condition were optimized. 


\section{Effect of $p H$}

To establish the optimum condition (stability of the product from the reaction of palladium(II) ion with the azo reagent, minimum blank value and relatively rapid reaction rate), the effect of $\mathrm{pH}(2.5-9)$ was studied. Only $\mathrm{pH} 4.0$ and 8.0 was found to be optimum for $\mathrm{Pd}(\mathrm{II})$ and $\mathrm{Ni}(\mathrm{II})$. Alkaline and acid results in low sensitivity and was not stable for $\mathrm{Pd}(\mathrm{II})$ and $\mathrm{Ni}$ (II) respectively. $\mathrm{pH}$ change on the electronic absorption spectra of the complex was studied by adding a small amount of $\mathrm{NH}_{3}$ and $\mathrm{CH}_{3} \mathrm{COOH}$ and $0.05 \mathrm{M} \mathrm{HCl}$ and $0.05 \mathrm{M}$ of NaOH. The UV-Visible spectra of complexes gives the band centered at $498 \mathrm{~nm}$ for Pd(II) and at 433.5 $\mathrm{nm}$ for $\mathrm{Ni}(\mathrm{II})$. The bands appearing in the range of $270-320 \mathrm{~nm}$ are attributed to $\pi \rightarrow \pi^{*}$ transition. The other band observed in the region of 498 and $\mathrm{nm}$ is attributed to $\mathrm{n} \rightarrow \pi^{*}$ electronic transition ${ }^{30-32}$ for $\mathrm{Pd}(\mathrm{II})$ and Ni(II) respectively Figure 3 Table 1.

\section{Effect of regent concentration}

Various concentrations of APAR solution were added to a fixed amount of Pd(II) and Ni(II) $2 \mathrm{~mL}$ and $2 \mathrm{~mL}$ of $5 \times 10^{4-} \mathrm{M}$ where found enough to develop the color to its full intensity and give a minimum blank value and were considered to be optimum for the concentration range (0.2-3.0) $(0.6-2.2) \mu \mathrm{g} / \mathrm{mL}$ of $\mathrm{Pd}(\mathrm{II})$ and $\mathrm{Ni}(\mathrm{II})$ respectively Figure 4.

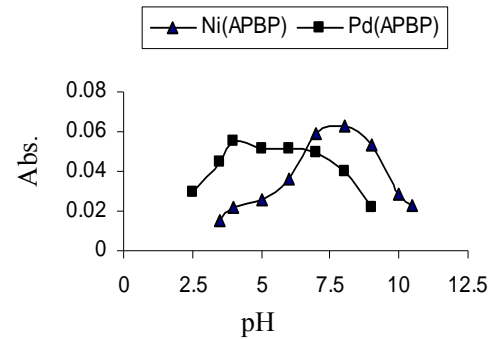

Figure 3. Effect of $\mathrm{pH}$

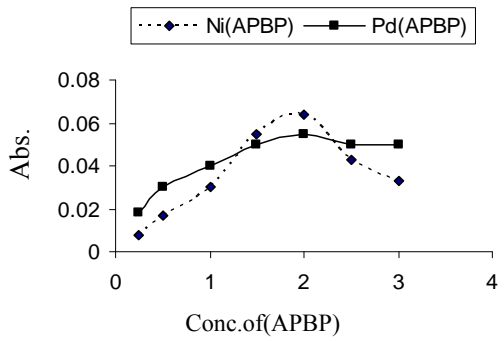

Figure 4. Effect of concentration

\section{Effect of reaction time}

The color intensity reached a maximum after the $\mathrm{Pd}(\mathrm{II})$ and $\mathrm{Ni}(\mathrm{II})$ has been reacted immediately with APBP therefore one minute development time was selected as optimum in the general procedure. The color obtained was stable for a least $24 \mathrm{~h}$ Figure 5.

\section{Effect of temperature}

The effect of temperature on the colour intensity of the product was studied. In practice, the same absorbance was obtained when the colour was developed at room temperature $\left(30-40{ }^{\circ} \mathrm{C}\right)$ a loss in color intensity and stability were observed, therefore it is recommended that the colour reaction should be carried out at room temperature for both complexes Figure 6 .

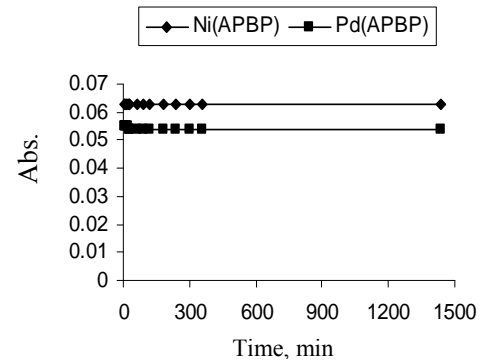

Figure 5. Effect of time

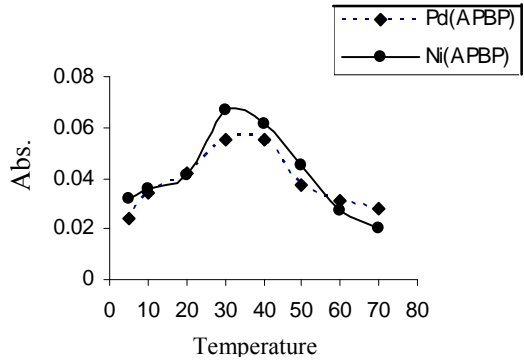

Figure 6. Effect of temperature 


\section{Order of addition of reagents}

To obtain the optimum results, the order of addition of materials should be followed as give by the procedure, otherwise a loss in stability was observed.

\section{Calibration graph}

At optimum conations, a linear calibration graphs for $\mathrm{Pd}(\mathrm{II})$ and $\mathrm{Ni}(\mathrm{II})$ were obtained, that Beers low is obeyed over the concentration range of 0.2-3.0 ppm and 0.6-2.2 ppm with a correlation coefficient 0.9986 and 0.9861 respectively. The results of analytical performance are summarized in Table 1.

Table 1. Analytical characteristics of Pd-APBP and Ni-APBP complexes

\begin{tabular}{ccc}
\hline Characteristic & $\mathrm{Pd}(\mathrm{II})$ & $\mathrm{Ni}(\mathrm{II})$ \\
\hline Absorption maxime, $\mathrm{nm}$ & $498 \mathrm{~nm}$ & $433.5 \mathrm{~nm}$ \\
Berr's low range, $\mu \mathrm{g} / \mathrm{mL}$ & $0.2-3.0$ & $0.6-2.2$ \\
Ph range & $4-7$ & $7-9$ \\
Sandell 'S sensitivity $\mu \mathrm{g} . \mathrm{cm}^{-2}$ & 0.05 & 0.015 \\
Molar absorptivity, L.mole ${ }^{-1} \mathrm{~cm}^{-1}$ & $0.21 \times 10^{4}$ & $0.38 \times 10^{4}$ \\
Stability constant, L.mol & $0.37 \times 10^{8}$ & $0.38 \times 10^{8}$ \\
\hline
\end{tabular}

\section{Interferences}

The effect of diverse ions in the determination of these metal ions was studied. To test of diverse ions were determined by the general procedure, in the presence of their respective foreign ions. In the experiment, a certain amount of standard palladium(II) or nickel(II) solution, coexisting ion solution and masking agent (or absence of masking agent) were added. The results are listed in Table 2.

Table 2. Effect of foreign ions

\begin{tabular}{cccc}
\hline Foreign ion & $\begin{array}{c}\text { Amount added } \\
\mu \mathrm{g} / \mathrm{mL}\end{array}$ & $\begin{array}{c}\text { Interferences with } \\
\mathrm{Pd}(\mathrm{II})\end{array}$ & $\begin{array}{c}\text { Interferences } \\
\text { with Ni(II) }\end{array}$ \\
\hline $\mathrm{Fe}^{+3}$ & 100 & -100 & +36 \\
$\mathrm{Fe}^{+2}$ & 100 & -89 & +29 \\
$\mathrm{~V}^{+5}$ & 100 & -23.6 & -3.2 \\
$\mathrm{Mo}^{+3}$ & 100 & +12.7 & +4.6 \\
$\mathrm{~W}^{+2}$ & 100 & +5.4 & +3.2 \\
$\mathrm{Ag}^{+1}$ & 100 & +14.5 & +1.6 \\
$\mathrm{Cr}^{+3}$ & 100 & +1.8 & +2.1 \\
$\mathrm{CO}^{+2}$ & 100 & +25.4 & +15 \\
$\mathrm{Hg}^{+2}$ & 100 & +10.9 & +1.1 \\
$\mathrm{Cd}^{+2}$ & 100 & +2.7 & +4.3 \\
$\mathrm{Pd}^{+2}$ & 100 & +25.4 & +21.4 \\
$\mathrm{Cu}^{+2}$ & 100 & +36.3 & +16.8 \\
$\mathrm{Cl}^{-1}$ & 100 & +63.3 & -44 \\
$\mathrm{SO}_{4}^{-2}$ & 100 & +81.8 & +1.4 \\
$\mathrm{CO}_{3}^{-2}$ & 100 & +69 & +16 \\
$\mathrm{NO}_{3}^{-2}$ & 100 & +69 & +20 \\
\hline
\end{tabular}

In the experiment, a certain amount of standard palladium(II) solution coexisting ion solution and masking agent (or absence of masking agent) were added. It is found that large amount of $\mathrm{W}^{2+}, \mathrm{Cr}^{3+}, \mathrm{Cd}^{2+}, \mathrm{Na}_{2} \mathrm{HPO}_{4}$, tartaric acid and citric acid do not interfere in the 
determination of $\mathrm{Pd}(\mathrm{II})$ and $\mathrm{Ni}(\mathrm{II})$ by comparing in the presence of masking agents $\mathrm{Na}_{2} \mathrm{HPO}_{4}$, tartaric acid and citric acid test cations. It's found that $\mathrm{Cu}^{++}, \mathrm{Co}^{++}, \mathrm{Mo}^{++}, \mathrm{V}^{5+}, \mathrm{Ag}^{+}$and $\mathrm{Fe}^{3+}$ interfere seriously. However, their interferences are masked efficiently by addition of $1 \mathrm{~mL}$ of $(0.1 \mathrm{M}) \mathrm{NaHPO}_{4}, 0.5 \mathrm{~mL}$ of $(0.1 \mathrm{M})$ tartaric acid and $0.5 \mathrm{~mL}$ of $(0.5 \mathrm{M})$ citric acid.

\section{Conductivity measurements}

The solubility of the complexes in dimethy sulfoxide and ethanol permitted of the molar conductivity of $10^{-3} \mathrm{M}$ solution at $25{ }^{\circ} \mathrm{C}$ and by comparison, the electrolytic nature for complexes. The low values of the molar conductance data listed in Table 3 indicate that the complexes are non electrolytes.

Table 3. Conductivity values of complexes

\begin{tabular}{|c|c|c|}
\hline \multirow{2}{*}{ Complex } & \multicolumn{2}{|c|}{ Molar conductivity, $\mathrm{S}$ mole $\mathrm{cm}^{2}$} \\
\hline & DMSO & Ethanol \\
\hline $\mathrm{Pd}(\mathrm{APBP})_{2} \mathrm{XH}_{2} \mathrm{O}$ & 0.72 & 1 \\
\hline $\mathrm{Ni}(\mathrm{APBP}){ }_{2} \mathrm{XH}_{2} \mathrm{O}$ & 2.4 & 4.1 \\
\hline
\end{tabular}

\section{Composition of the complexes}

The FT.IR bands of the (APBP) and its palladium(II) complex with their probable assignment are give in Table 4 . The stretching band of $v(\mathrm{~N}=\mathrm{N})$ in the free ligand is observed at $1557 \mathrm{~cm}^{-1}$. This band is shifted to lower with low intensity $1510 \mathrm{~cm}^{-1}$ frequency value upon complexation. Also the FT-IR spectrum of the ligand revealed a sharp band at $1645 \mathrm{~cm}^{-1}$ due to $(\mathrm{C}=\mathrm{O})$. This band is shifted to lower with low intensity $1593 \mathrm{~cm}^{-1}$ frequency in the complex indication to the metal ion ${ }^{33,34}$. The bonding of oxygen to the metal ion provided by the occurrence of bands at $515 \mathrm{~cm}^{-1}$ as the result of $\mathrm{v}(\mathrm{M}-\mathrm{O})^{35}$.

Table 4. Selected IR data of (APBP) and its complexes with $\mathrm{Pd}(\mathrm{II}) \& \mathrm{Ni}(\mathrm{II})$

\begin{tabular}{cccccc}
\hline Compound & $v(\mathrm{C}=\mathrm{N})$ & $v(\mathrm{~N}=\mathrm{N})$ & $v(\mathrm{C}=\mathrm{O})$ & $v(\mathrm{M}-\mathrm{O})$ & $v(\mathrm{M}-\mathrm{N})$ azo \\
\hline $\mathrm{H}_{2} \mathrm{~L}$ & $1645 \mathrm{~s}$ & $1557 \mathrm{~m}$ & $1645 \mathrm{~s}$ & - & - \\
{$\left[\mathrm{Pd}(\mathrm{HL})_{2}\right] \mathrm{XH}_{2} \mathrm{O}$} & $1531 \mathrm{~s}$ & $150 \mathrm{~m}$ & $515 \mathrm{w}$ & $515 \mathrm{w}$ & $430 \mathrm{w}$ \\
{$\left[\mathrm{Ni}(\mathrm{HL})_{2}\right] \mathrm{XH}_{2} \mathrm{O}$} & $1535 \mathrm{~s}$ & $1520 \mathrm{~m}$ & $1585 \mathrm{~s}$ & $520 \mathrm{w}$ & $435 \mathrm{w}$ \\
\hline
\end{tabular}

S: sharp, m: medium, w: weak

The composition of complexes was studied in the excess of reagent solution by the mole - ratio method. A break at a 1:2 (M:L) mole ration suggested the formation of both complexes where $\mathrm{M}=\mathrm{Pd}(\mathrm{II}), \mathrm{Ni}(\mathrm{II})$ and $\mathrm{L}=\mathrm{APBP}$ under the given condition Figure 7, 8 .

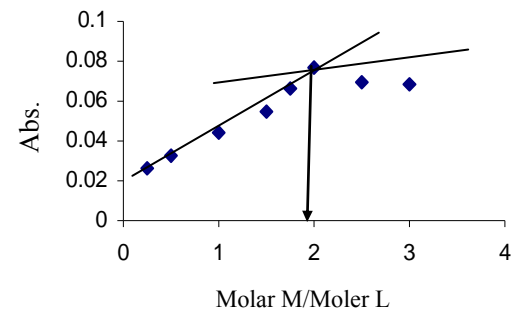

Figure 7. Mole-ratio method of $\mathrm{Ni}$-Complex

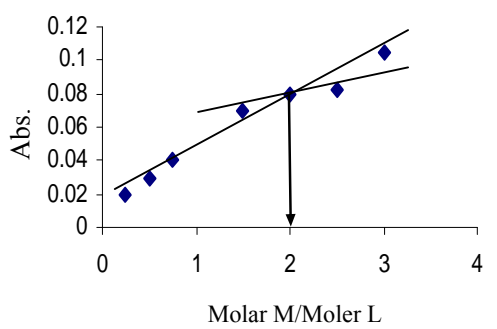

Figure 8. Mole-ratio method of Pd -Complex 
On the basis of FT-IR and stoichiomtric data the structure of complex can by suggested as follows Figure 9.<smiles></smiles>

$\mathrm{X} \mathrm{H}_{2} \mathrm{O}$

Where $M=P d(I I)$ or $N i(I I)$

Figure 9. The proposed structural formula of complexes with (APBP)

\section{Application}

The propose method ware applied to the determination of $\mathrm{Pd}(\mathrm{II})$ in synthetic mixture were analyzed by the procedures described above and results displayed in Table 5 .

Table 5. Determination of Pd(II) in synthetic mixtures and Ni(II)

\begin{tabular}{ccc}
\hline Composition of mixture $\mu \mathrm{g} \cdot \mathrm{mL}^{-1}$ & $\begin{array}{c}\text { Found by present } \\
\text { method } \mu \mathrm{g} \cdot \mathrm{m}^{-1}\end{array}$ & $\begin{array}{c}\text { \%R.SD of the Pd(II) } \\
\text { and Ni(II) complex }\end{array}$ \\
\hline $\mathrm{Pd}^{++}(1), \mathrm{Mo}^{++}(10), \mathrm{Co}^{++}(10), \mathrm{Cd}^{++}(10)$ & 0.99 & 1.8 \\
$\operatorname{Pd}^{++}(1), \mathrm{V}^{+5}(10), \mathrm{pb}^{++}(10)$ & 0.98 & 1.7 \\
$\mathrm{Pd}^{++}(1), \mathrm{Cu}^{++}(10), \mathrm{Ni}^{+++}(10)$ & 1.02 & 2.3 \\
$\operatorname{Pd}^{++}(1), \mathrm{Fe}^{+++}(10), \mathrm{Ag}^{++}(10)$ & 1.04 & 2.2 \\
$\mathrm{Ni}^{++}(1), \mathrm{Fe}^{++}(10), \mathrm{Co}^{++}(10), \mathrm{Pd}^{++}(10)$ & 0.96 & 1.8 \\
$\mathrm{Ni}^{++}(1), \mathrm{Fe}^{+++}(10), \mathrm{Mo}^{++}(10), \mathrm{Cd}^{++}(10)$ & 0.97 & 1.2 \\
\hline
\end{tabular}

Determination of Pd(II) and Ni(II) in blood of human

The samples were collected from AL-Sadder hospital in Al-Kufa city in Iraq. $1 \mathrm{~mL}$ of blood were mixed with $1.5 \mathrm{~mL}$ of $\mathrm{H}_{2} \mathrm{O}_{2}$ and $4 \mathrm{~mL}$ of $5 \% \mathrm{HNO}_{3}$. Samples were left for $60 \mathrm{~min}$ and then ready for UV-Visible spectrophotometric analysis ${ }^{36}$ Table 6.

Table 6. $\mathrm{Pd}(\mathrm{II})$ and $\mathrm{Ni}(\mathrm{II})$ levels $\left(\mu \mathrm{g} \cdot \mathrm{mL}^{-1}\right)$ in blood samples

\begin{tabular}{ccc}
\hline $\begin{array}{c}\text { Ions in blood of } \\
\text { human }\end{array}$ & $\begin{array}{c}\text { Amount found by spectrophotometric } \\
\text { method, } \mu \mathrm{g} \cdot \mathrm{mL}^{-1}\end{array}$ & $\begin{array}{c}\text { Amount found by atomic } \\
\text { absorption method, } \mu \mathrm{g} \cdot \mathrm{mL}^{-1}\end{array}$ \\
\hline $\mathrm{Pd}(\mathrm{II})$ & 0.020 & 0.018 \\
$\mathrm{Ni}(\mathrm{II})$ & 0.012 & 0.011 \\
\hline
\end{tabular}

\section{Conclusion}

This method using APBP was successfully applied for the determination of palladium(II) and nickel(II). Because of the selectivity and sensitivity of the method, its application can be determination of those ions environmental and industrial samples. 


\section{References}

1. Vojkovic V and DruskovicV, J Corat Chem., 2003, 76(1), 87-92.

2. Weizu Y, Qiufen H, Zhangjie H, Jiayuan Y, Gang X and Jing C, J Serb Chem Soc., 2006, 71(7), 821-828.

3. Sakuraba S and Oguma K, J Anal Chem., 1994, 349, 523-526.

4. Vlasta V and Vinka D, CCACAA, 2003, 76(1), 87.

5. Zagorka K, Tatijana J, Jelena P and Dragica M, J Serb Chem Soc., 2004, 69(6), 489.

6. Vesna Vasic, Jasmina Savis and Nikloa Vukllc, J Serb Chem Soc., 2004, 69(4), 309-317.

7. Xingguang S, Meijia E, Yihua Z, Hangi Z and Qinhan J, J Anal At Spectrom., 2001,16, 1341-1343

8. John T B and Donald J E, Environ Health Perspectives, 1975, 12, 19-26.

9. Pourrezd N, Rastegarzadeh and Canadian S, J Anal Sci Spectrom., 2004, 49(5), 314.

10. Pooblasingam A, Gregory W Wildgoose, Lei X and Richard C, Electro Anal., 2008, 20(14), 1607-1609.

11. Karipcin F and Kabalcilar E, J Acta Chim Slov., 2007, 54(2), 242-247.

12. Kaeser A and Stingelin W, Eur Pat Appl., 1994, Ep591,103, C.A, 121, 233064F.

13. Ridyard D R A and Renfrew A H M, Eur Pat Appl., 1992, Ep471,456, C.A, 116, $196228 \mathrm{~m}$.

14. Awad I M, J Chem Technol Biotechnol., 1992, 35, 227.

15. AboEl-Ghar M F, Abdel-Ghani N T, Badr Y and El-Borady O M, J ISESCO Sci Technol Vision., 2007, 3(3), 58-63.

16. Iliadou E N, Voulgaropouls A N, Girousi S T, Dietze U, Otto M and Papadopoulos C G, Anal., 1997, 122, 597.

17. Naskar S, Biswas S, Mishra D, B Adhikary, L.R. Falvello, Soler T C.H. Schwalbe C H and Chattopadhy S K, Inorg Chim Acta, 2004, 357, 4257-4264.

18. Gup R and Kirkan B, Spectrochim Acta, 2005, 62(4-5), 1188-1195.

19. Afkhami A and Bahram M, Spectro Chem Acta Part A, 2004, 60, 181.

20. Chang H J, Sung Y H and Huang S D, Analyst, 1999, 124, 1695.

21. Wang H, Miao Y X, Mou W, Zhang H and Cheng J K, Mikrochim Acta, 1994, 117, 65-74.

22. Ghe A M, Lippolis M T and Pastorelli L, Talanta., 1985, 32, 949-952 .

23. Huang Y L, Tsai Y F and Lin T H, Anal Sci., 1999, 15, 79.

24. Lin P H, Danadurai K S K and Huang S D, J Anal At Spectrom ., 2001, 16, 409 .

25. Vicenta S, Maniasso N, Queiroz Z F and Zagatto E A, Talanta., 2002, 57(3), 475-480.

26. Yunes N, Moyano S, Cerutti S, Gasquez J A and Martinez L D, Talanta, 2003, 59(3), 943-949.

27. Fan X Z and Zhu CH, Microchem J., 1998, 59, 284.

28. Ferreira S L C, Talanta Anal Chim., 1988, 35, 485.

29. Farukawa M and Shibata S, Anal Chim Acta, 1982, 140, 301.

30. Ohshita K, Wada H and Nakagawa G, Anal Chim Acta, 1982, 140, 291.

31. Vogel A I, A Text book of partical organic chemistry, $3^{\text {rd }}$ Ed., Longmans London, 1962.

32. Naskar S, Biswas S, Mishra D, Soler T, Adhikary B, Falvelloand L R and Chattopadhyay S K, Inorg Chim Acta, 2004, 357, 4256.

33. Harvey A E and Manning D L, J Am Chem Soc., 1950, 72, 4488.

34. Zaki Z M, Spectrochim Acta Part A, 2000, 56, 1917.

35. Omar M and Mohamed G, Spectro Chim Acta Part A, 2005, 61, 929-936.

36. Barvera H and Vinas J M, Trant Met Chem., 1985, 10, 233. 


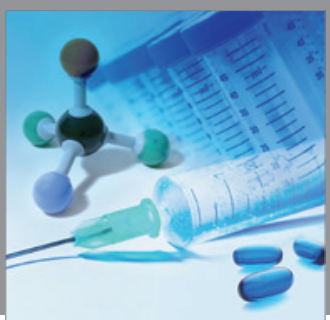

International Journal of

Medicinal Chemistry

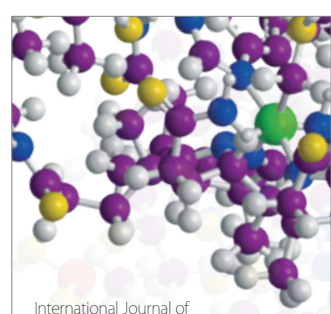

Carbohydrate Chemistry

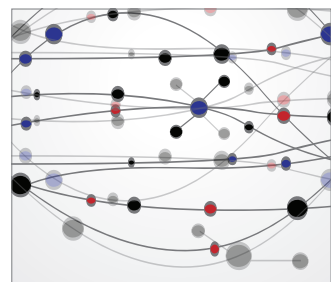

The Scientific World Journal
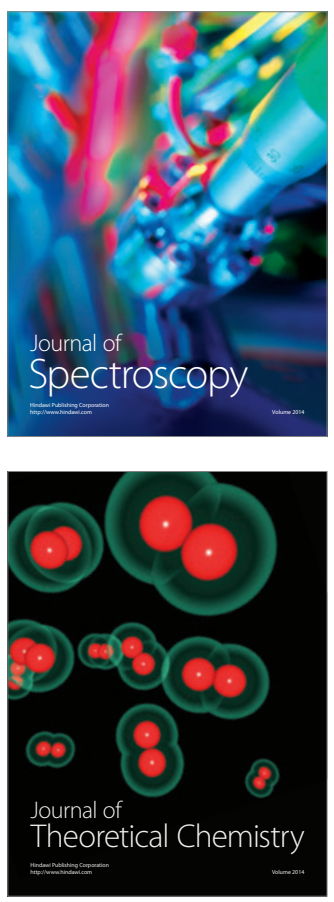
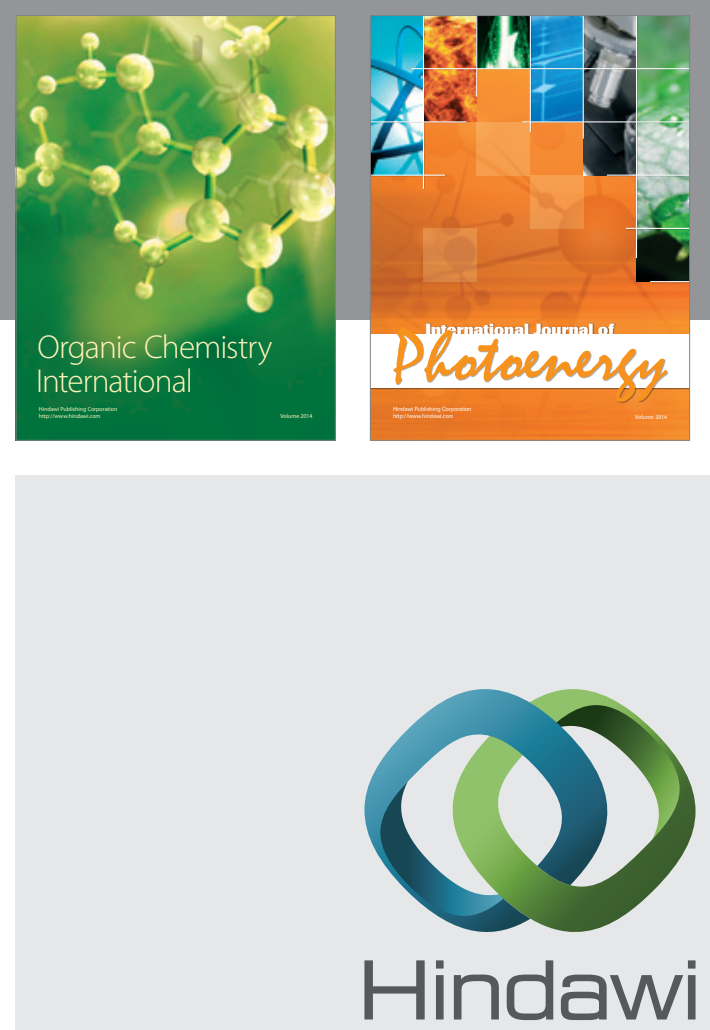

Submit your manuscripts at

http://www.hindawi.com
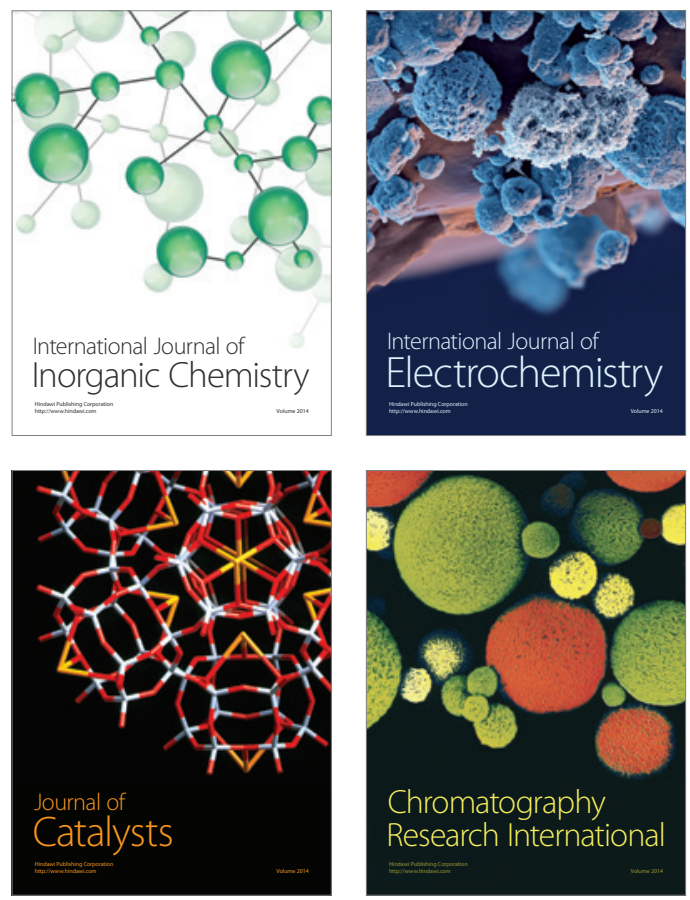
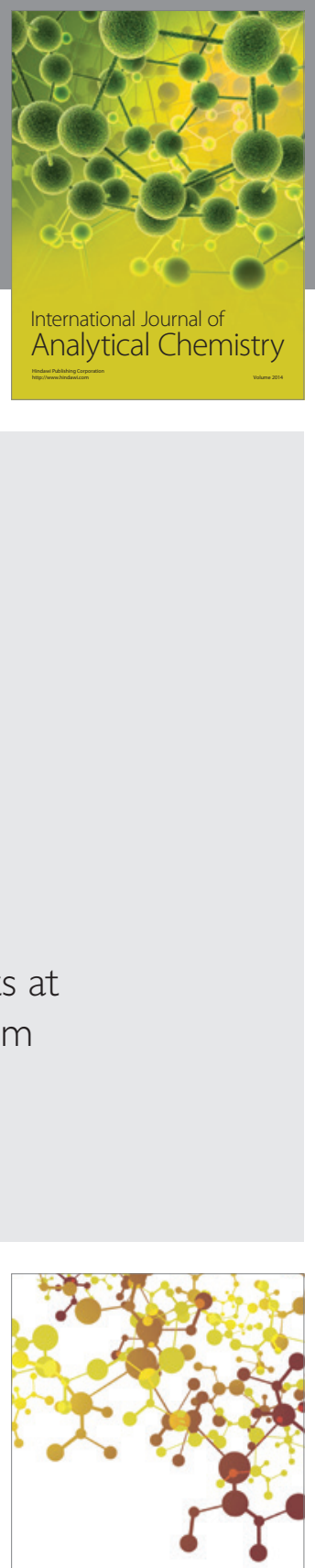

Journal of

Applied Chemistry
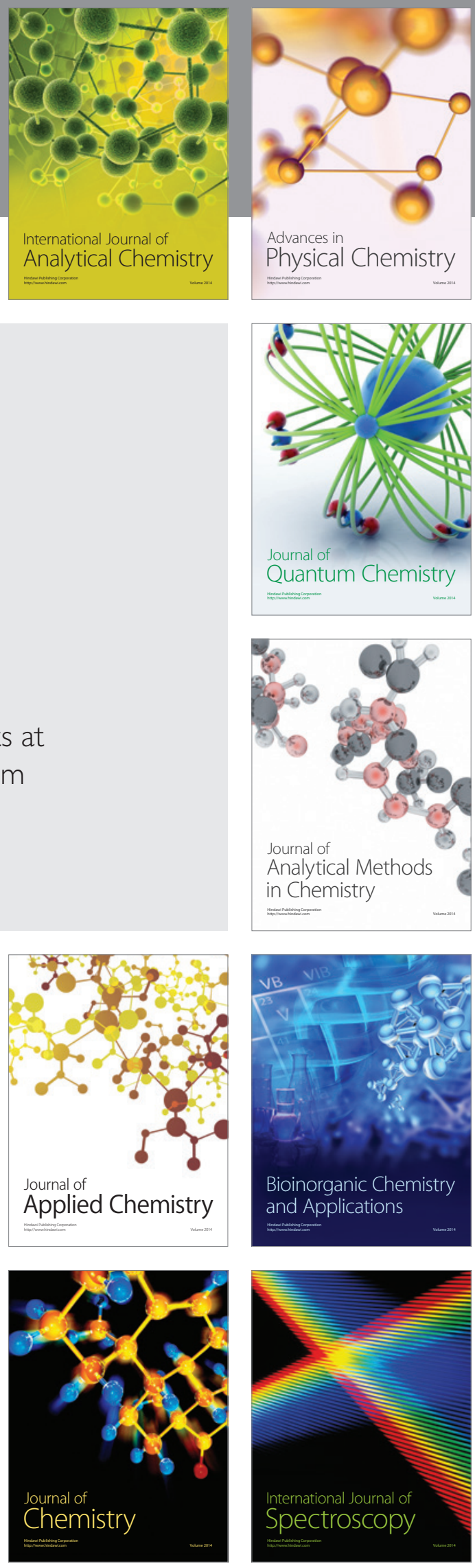